\title{
産業競争力強化と知的財産
}

\author{
丸島儀一 \\ 著者抄録: 知的財産, 特許の世界は近年非常に注目されており, 大きく変化している。わが国を見る \\ なら, 日本経済再生のキーとして, 知財立国という国家戦略が立てられた。また日本の産業競争力 \\ はかつての世界を席巻していた時代と大きく変わり, 現在低下している。一方, 米国は1980年代に \\ 入ってプロパテント政策をとり, 結果, 産業競争力は回復し, さらに強化されている。米国では, 知 \\ 財戦略として税制面での配慮, バイ・ドール法の施行, ベンチャー企業の活性化, CAFCによる特許 \\ 訴訟の判決の統一化などを実施してきた。日本では日本版プロパテント政策を目指しつつ, 知的財 \\ 産戦略大綱の中で関連項目を取り入れている。研究開発投資に見合うリターンが期待できる環境整 \\ 備, 例えば発明に対し適切で強い権利を与える, 権利の保護の対象を広げるなどの整備, 研究開発 \\ におけるオリジナリティーの重視, いわゆる創造の重要性, それら創造的活動を大学に期待する, 特 \\ 許訴訟の判決の統一化, などである。また, 産学連携の重要性, 大学での知的財産戦略の重要性に \\ ついても述べた。また, 企業が知財に対してとるべき戦略, 知的財産部の人たちのなすべきこと, な \\ どについても触れた。 \\ キーワード : 産業競争力, 知的財産, 知財立国, 国家戦略, プロパテント政策, 米国, バイ・ドー \\ 儿法, CAFC, 特許訴訟, 知的財産戦略大綱, 産学連携
}

\section{Industrial competition and intellectual property}

\section{MARUSHIMA Giichi}

Author Abstract: Intellectual property and patents have been attended over the world in the recent years, and have been drastically changing. Looking at Japan where economic recession has been long spreaded over the nation, they are considered to be keys for her economy recovery as seen in that the Japanese Government formulated the national strategy titled a nation based on her intellectual properties. Actually Japan's industrial competition used to conquer the world, but it is now going downward. On the other hand the US has executed pro-patent policy since the 1980's resulting that her industrial competition not only has recovered but also has been enhanced. She incorporated some treatments favoring the taxation, Bayh-Dole Act, vitalization of venture firms, a unified decision by CAFC for patent suits. Aiming at Japanese-version pro-patent policy Japan has incorporated the followings in the Intellectual Property Strategy General Outline by the Government: consolidation of the environment where ones are able to obtain returns to $R \& D$ investment they have done including strong patent right assigned, enlarged coverage of the right; significance in originality and creativity for R\&D; role of academic communities for creative research activities, unified decision of patent suits, so on. He also describes importance of industry-academia cooperation, and importance of intellectual property strategy in universities/colleges. Strategies which firms should take and what personnel of intellectual property departments inside firms should do are also mentioned.

Key words: industrial competition, intellectual property, nation based on intellectual property, national strategy, pro-patent policy, the United States of America, Bayh-Dole Act, CAFC, patent suit, Intellectual Property Strategy General Outline, industry-academia cooperation 


\section{1. 変化した知的財産の世界}

私は40年間知財の仕事をしてきました。振り返 りますと,この知的財産の世界は大変, 変化した と思っています。最近では, 総理大臣が戦略会議 を開いて「知財立国」ということで国家戦略を立 てられました。これは歴史始まって以来のことだ と思います。私が仕事を始めた 40 年前は知的財産, 特許ですが,一般の関心も高くありませんでした。 この 40 年間の特許への関心の変化の理由はいろ いろありますが, その大きな点は日本の産業競争 力の低下にあると思います。産業競争力が旺盛で, 日本が世界を席巻していた時代，このころも知的 財産は大事であったに違いなく, 実際のところい ちばん大事だったと思うのですが，それでも総理 大臣自ら戦略をリードすることはありませんでし た。個々の企業がそれぞれの戦略で賄っていたわ けです。今は, 産業競争力が弱まり，これを国家 戦略として考えないと日本の産業競争力が強まら ないという認識から発しているのです。

極端な例ですが, 企業はグローバル展開につれ て日本にいる必要がなくなります。生産の海外シ フトです。次いで, 研究開発を効率良くするため に研究開発がシフトしつつあります。このまま放 置すると, 国益という観点から見たら, おそらく 日本の産業力はますます下がっていくと思います。 このあたりが具体的な危機感として背景となって いると思います。では, なぜ研究開発がシフトす るようになったか。それは企業の置かれた立場が 以前とはだいぶ変わったからです。基本技術を導 八して, それを改良して, 良い製品, 良い品質の 製品を世界に提供して, わが国が栄えてきたわけ です。これでいちばん被害を受けたのは米国です。

1980年代半ばから後半に至って, 本当にみじめ なほど米国は日本によってその競争力を下げられ てしまいました。日本がその分, 米国の市場を席 巻してしまったのです。このような状況下では, 企業戦略に任せておけばよいし，もしくは大きな 意味で護送船団方式が作用したでしょう。日本は 物づくりにいちばん得意な力を発揮したのです。

ところが今は，欲しい基本技術の導入ができな くなっています。では, 得意とする改良と生産の メリットはどこへ行ったのでしょうか。発展途上 国からの追い上げがあります。上と下から挟み打 ちを受けているのが今の日本の状態だと思います。 したがって, 企業が非常に苦境に立ってしまって います。企業が自前で研究開発ができなくなった

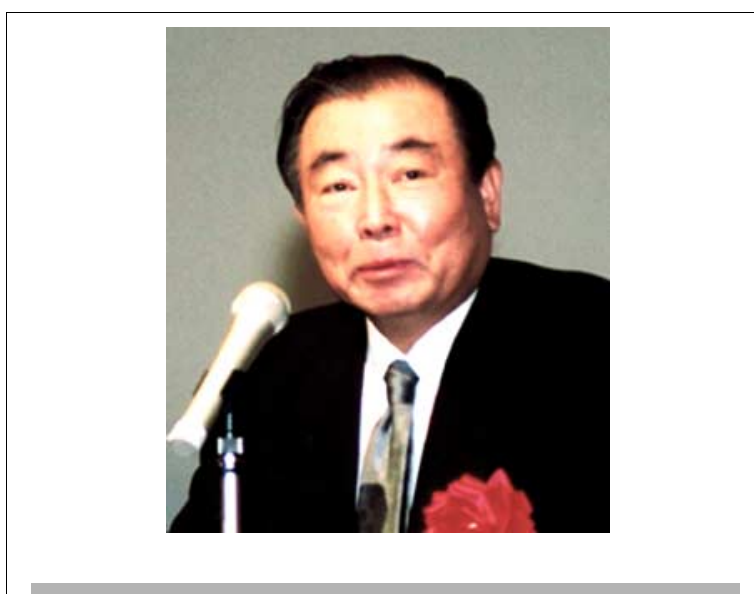

\section{丸島儀一氏略歴}

1934 年東京生まれ。1960 年 3 月早稲田大学卒業後, キヤノンカメラ（現キヤノン）に八社。1972 年特許 部長，1983 年取締役就任を経て 1999 年に専務退任。 現在は同社顧問。( 社 ) 経済団体連合会 産業技術委 員会 知的財産部会長, (社) 日本国際工業所有権保 護協会副会長，文化審議会著作権分科会委員。

理由があります。これは私の考えですが，1つはア メリカナイズされてきた企業経営です。株主重視 で, 経営者が株主に向かって目を向けなければな らなくなりました。つまり毎期, 毎期に何らかの 利益を上げなくてはならず，したがって, 長期に わたる投資に冒険的なことができなくなってしま いました。研究開発についても短期的な方向に向 かわざるをえないのです。

もうひとつは技術の変化だと思います。アナロ グの時代は, 人に影響されないで, 自分の技術が 良ければ10年でもじっくり研究開発して, それを 事業に仕立てていく。それで立派に競争力のある 製品ができたと思います。ところが, 技術がアナ ログからデジタルに変わり, 製品はネットワーク 中の1構成部分になってしまいました。私どもの会 社の製品を見ましても, 複写機もプリンターもカ メラも, みんなネットワークにつながらないとお 客さんは採用してくれないわけです。これは自社 のネットワークだけではなく, 共通のネットワー クに各社の製品がつながらなければならないとい うのが現状です。

そうすると, 必然的にネットワークにつながる ための約束事が必要になってきます。これが技術 標準です。技術標準があるがために，1社だけで一 生懸命研究開発して技術を完成させ事業をつくろ うとしても, その間の世の中が, 特に標準化技術 が急速に変化してしまい, 結果, 自社の技術を完 
成しても標準化に乗らないと市場に採用されませ ん。すなわち, 研究開発そのものが自身でできな いのです。いわゆる標準化の動きと連動させなけ ればならない。他人に影響される度合いが非常に 強くなったと言えます。さらに，技術があまりに も速く変化しすぎています。よって長期的な投資 をするリスクが非常に高くなってしまった。こう いう状況下で日本の企業は, 従来ですと中央研究 所, あるいは基礎研究所とか応用研究所など, 自 前で全部やっていたのですが，今は基礎的な部分 というのをやれなくなってしまった。せいぜい忍 用研究開発が精一杯になっているのだろうと思い ます。そういう状況にもありまして,いったんトッ プレベルに立った日本の企業がそれを維持するの は非常に難しくなってきました。

\section{2. 復帰した米国の産業競争力}

そして米国も，だんだん自身の状況を换回する 施策をとり，一時どん底に落ちていた米国の産業 競争力も今はまた復活して, 世界ナンバーワンの 立場を取り戻したわけです。これは米国がとった プロパテント政策の結果だったのです。1984年, レーガン大統領の時代ですが, ヤング・レポート という, 今のヒューレット・パッカード会長のヤ ングさんが産業界からレポートを出しました。こ れが始まりと言われているのですが, 実は1980年 の頭ごろからいろいろな産業競争力強化策がとら れていました。

1つは税制面の配慮です。米国はそれまで独占禁
止政策が非常に強くて,グループの系列一垂直・ 水平の共同研究なども禁止されていましたが，そ れを全部解除して自由にさせました。当時, 日本 に向かっては「系列がけしからん」といろいろ批 判した時代だと思いますが，自国では研究開発を 自由にした,そういう施策をとりました。次に, 軍 の技術を民におろしました。いちばん大きいのは バイ・ドール法で, 国の予算での研究開発につい て，以前は成果である特許権を国のものにしてい ましたが, 研究開発した者に与えられるという方 針にしました。1980年代初頭に中小企業の研究者 に，1983年ごろは普通の企業に対してもそれを適 用しました。これが非常に効果をもたらし, 企業 の活性化, ベンチャーの活性化に役立ちました。

もうひとつ, ベンチャーが活性化した要因は, 米国はソフトウエアが非常に得意だったことにあ ります。ソフトウエアは著作権で保護されていま すが，自身で創作したソフトウエアは人の権利に 影響されません。まねしてはいけないのですが， たとえ同じものであっても, 自身が創作したなら， それを事業にするのは自由です。

ここが成果に対する特許権とまったく違うとこ ろです。特許をとったら，その技術を独占的に実 施できると考えると思いますが，これは間違いで す。特許をとっても，その技術を実施できる保証 はありません。特許権というのは排他独占権です。 ですから，特許をとったなら，その技術を他人に 実施させないという権利です。反面，自分が特許 をとったからといって自分がその技術を実施でき るという保証もないわけです。自分の特許の技術

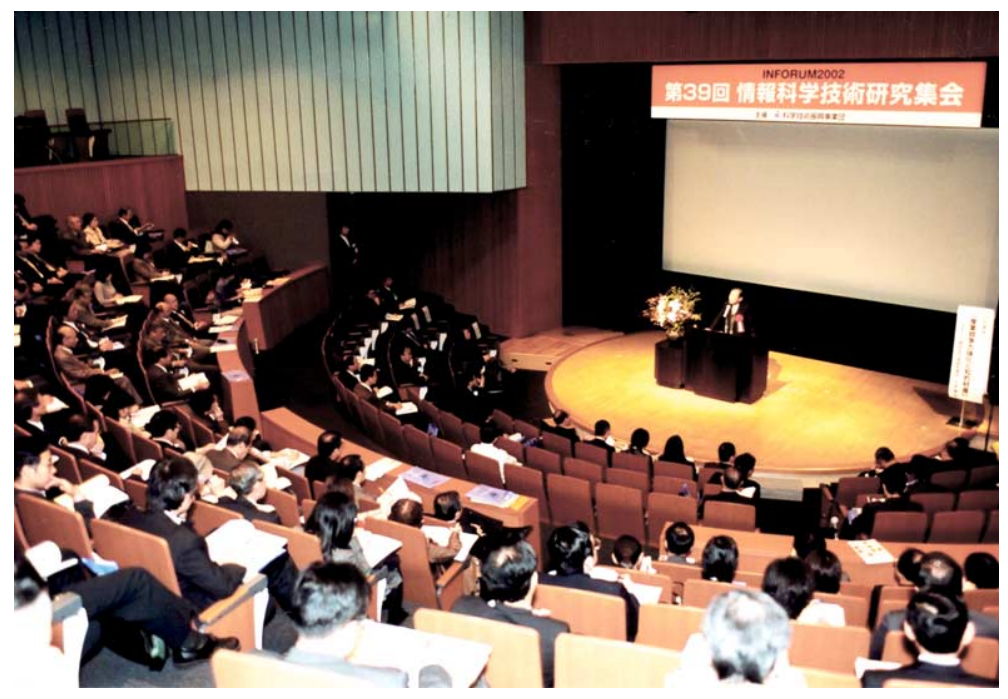

みらいCANホールで講演する丸島氏 
がそれより前の第三者が所有する特許の排他権に 影響されることがあるからです。

また, 薬や化学の分野の製品や部品であれば, ひとつの発明（特許）で新しい製品を創ることが できる場合もあると思いますが, 情報産業分野の 製品の場合はほとんど不可能です。

ベンチャーの立場を考えてみましょう。ベン チャーの方があるひとつの発明をしました。それ を実際に事業化しようとする場合，自身の発明だ けでは製品は創れません。ほかの技術も絶対必要 なのです。カメラの例で言いますと, 性能の優れ たレンズを発明し，それが付いたカメラをつくれ ばおそらく良い製品になるとして，レンズの発明 をもとにカメラ事業に着手します。レンズのつく り方, 使う材料等々いろいろな特許がそこには介 在します。それらをクリアしないと, せっかくの 発明のレンズもつくれません。レンズ関連がクリ アできたとしても, カメラをつくる際のカメラの ボディにたくさんの特許が存在します。それらの 特許もクリアしないと事業はできません。これが ハード系のベンチャーの悩みなのです。

では,ソフトウエアはどうでしょうか。例えば コンピュータのソフトウエアですと, ソフトウエ アそのものが良ければ, ほかの人のソフトウエア の権利に何ら影響されずに事業ができます。この 分野でべンチャーが大変に活性化したのは, ひと つにそこで扱う技術分野がものをいったと思いま す。そういう活性化の状態をつくったうえで, プ ロパテント政策をとったわけです。

\section{3. プロパテント政策の効果}

それと, 前述した実状の前に裁判所の変化があ りました。米国はご承知のように広い国です。地 方裁判所は各州にありますし, 高等裁判所も9つく らいあります。ところが, 各裁判所の判断がまち まちですので, 統一した判断ができませんでした。 それをCAFCと言われる連邦巡回控訴裁判所を控訴 審の専属管轄にしてしまったのです。ですから， そこへ特許訴訟が全部集まり控訴審を裁くととも に判決の統一を図るようになったわけです。

そうしますと, その裁判所の判決が米国の特許 に対する解釈ということで定着するようになりま した。ここがいちばんのミソでして, 米国では司 法も立法も全部同じ行政の方向にベクトルを合わ せるのです。これは日本と大きく違うところだと 思います。裁判所の判断がプロパテントに軸足を
置いた判断に変わっていきました。つまり, 従来 は侵害訴訟で訴えると, 特許権者の特許が7割方無 効という判断が出ましたが, プロパテント政策施 行以来, それが逆転して, 無効となる数が少なく なってしまったのです。

もうひとつは, 従来は特許権の広さを裁判所が 判断するときに，書いてある文言の幅で権利の広 さを解釈していたのですが，プロパテント政策以 来, 均等論を適用して,書いてある文言よりももつ と幅を広めた権利があるという論理を展開してい きましたので, 権利者に有利な判決が出るように なったわけです。

米国の場合は, 特許権侵害事件でも陪審がつき ます。つまり事実認定は陪審で行います。その地 域の人たちが話を聞いていて, どっちが正しいか と判断するわけです。裁判官は法律マターしか関 与できません。事実認定で侵害と出ると侵害にな ります。もうひとつは, 例えば地裁の段階で侵害 の判決が出ると, その段階で差し止めが執行され るので，事業が止まってしまいます。

コダックとポラロイドの訴訟が思い出されます。 ポラロイドカメラの件ですが, 結局ポラロイドが 勝ち，コダックが市場にある敗訴した自社のポラ ロイド方式のカメラを全部回収しました。つまり, 訴訟に負けると撤退せざるをえない。これは経営 者に大変なインパクトを与えました。

さらに, 敗訴した場合の損害賠償額が高騰し, 特に故意に侵害した場合は3倍の賠償額の支払いが 判示され, 事業採算がとれなくなってしまいます。

こういうCAFCの判決そのものがプロパテント政 策に沿った判決を出したので, 米国の企業は知的 財産の価值観をとても高めました。これが日本の 企業に対する知的財産攻撃を強めたのです。つま り, 裁判に持ち込む以前の示談・交涉です。特許 権侵害のクレームを持ち込まれると, 多くの日本 の経営者はコダックの例を見ても「事業が止まる のは大変だ」という危惧を持ち, 高額の金を支払 うという示談で自らの事業は継続するということ を余儀なくされました。

米国ではこのようなプロパテント政策のほかに, 米国の最先端の技術は外国には出さないという方 針をとりました。安い製品が国外から入ってくれ ば, ダンピングで取り締まる, 税関での扱いも非 常に厳しくするといった施策をとってきています。 さらに, 国際貿易委員会 (ITC) が裁判所より早く 侵害の判断をして外国からの製品の米国への上陸 を止めてしまいます。これがまた外国の経営者に 
対して非常な驚異を与えました。特許権を侵害し たら製品は米国に輸出できない。その製品が米国 企業に対する供給であると，その企業に対し供給 の約束違反といった損失を与えるので, 損害賠償 の対象になってしまいます。これやあれやで，権 利侵害が及ぼす影響が甚大であるので, 特許権を 尊重し，いわゆる特許権侵害の抑止力を与えるの がプロパテント政策の効果だと思います。

\section{4. 環境整備と創造活動}

今，日本の産業競争力は下がっています。日本 は米国がとっている政策をほとんど模倣しょうと しています。知的財産戦略大綱の中にそれが盛り 込まれています。しかし, 米国と日本とではマー ケットの規模の違いを認識する必要があります。 米国という巨大マーケットと切り離して日本は成 り立ちません。米国の良いところは採用しつつも， マーケットの大きさの違いを前提にして戦略を立 てなければいけないと思います。

産業界が日本の知的財産戦略に望むことは, 企 業が日本で研究開発をしたいという気持ちを持つ, あるいは日本の企業だけではなく，外国の企業， もしくは研究者が日本で研究活動をしたい, ある いは日本で事業をやりたいという気を起こさせる ような環境をまずつくることだと思います。これ が国家戦略だろうと私は思います。オリジナリ ティーの高い研究開発に投資をすれば，それに見 合うリターンが得られる環境をつくることが大事 です。つまり研究開発成果に対して適切に，かつ 広く強い権利を与えるとともに, 実効ある権利の 活用と適切な保護が与えられる環境をつくること です。

それから，保護の対象を広げることです。例え ばソフトウエアにもビジネス方法にも特許が付与 されるようになりました。特許法の改正です。従 来の法律でもそれらは保護できたという解釈もあっ たのかもしれませんが, もともと知的財産という のは無形の財産で, 民法, 民事訴訟法という大き な一般法の中での特別法として特許法があるので すが，民法自身は有体物を対象にしています。

今, バイオでいろいろ問題になっていますが, あれも情報の一種です。知的財産は情報に権利を 与える方向にどんどん来てしまっています。した がって発明の定義を変える必要があるかもしれま せん。しかも科学技術基本計画の下, 国家予算を 研究開発に5年間で24兆円投入することになってい
ます。ここでの成果が現在特許の対象になってい ない新分野に向かうとすれば, それらを速やかに 特許にする仕組みを築かないと, 欧米に後れをとっ てしまうことが起きましょう。

ひとつの例として医療を挙げます。医療は産業 ではないと定義されています。医療機器は特許の 対象になるのですが, 問題は, 特許をとるのに人 間の体の部位が明細書の中に条件として入ってい ると, 特許にならないことです。外国では特許に なります。日本では表現のしかたで特許になった りならなかったりします。例えば, ナノテクノロ ジーの発達につれ人体とのかかわりは密接になる と思います。したがって医療機器産業の発展と医 療技術の進歩のため, 医療も特許の対象にしたら どうか。問題は権利行使をどこまで認めるかで, 医者の治療を特許権で妨害するのはいけない, だ が権利は付与するという考えを早く持ち込まない と, 知的財産上の優位性は日本には出てこないと 私は思います。

さらに肝心なことは, 環境整備ができたとして も創造がなければだめです。知的財産戦略大綱は 国家戦略であるので, 国家が行う範ちゅうで創造 の部分が表現されています。つまり大学の責務お よび国の責務です。企業も当然創造の母体なので すが, 大綱には表現してありません。では知的財 産基本法ではどう表現されているか。そこには「企 業の責務」という表現が入っています。「企業も発 明をし, 自身ないしは他の人, あるいは大学によ る発明の創造的な技術を積極的に活用する」とい う責務が明確に書いてあります。そして,「創造活 動に従事する人を適切に処遇する」のは企業の責 務であると書かれています。

創造が真の意味で世界的レベルに達しないと， 環境整備がかえってあだになるという感じを持ち ます。プロパテント政策をとった以上は, 創造活 動でトップレベルにいく必要があります。大学の 役割は大きいのです。米国を見ても，そこでの企 業は自前で全部やっていません。でも産業競争力 は非常に高い。その理由は, 環境の整備と, 必要 な時期に必要な技術と人材を米国の国内でアウト ソーシングできることなのです。これは大学との 連携, 研究所との連携, ベンチャーとの連携でで きたのです。

日本国内でそういう環境がないと企業は海外へ 出ていきます。したがって, 国内で創造できる環 境をつくるのが大前提で, 経済界としてもそれを 大学に期待したいと願っています。そこで, 大学 
の使命の議論が出ると思います。教育, あるいは 基礎研究が使命であるのは当然ですが, それに加 えて産業に軸足を置いた研究もしてほしいと願い ます。これがうまく機能しないと国力は回復しな いと私は考えます。先ほど, アウトソーシングで 創造的技術を外国に求めればよいと申しましたが, 相手方に拒絶されれば日本の国内で調達するより しかたなくなります。創造戦略のもとは大学とさ れますので, 大学の改革, 特に競争原理の導入と か, 産学連携の円滑化などが望まれるところであ り，現実にその方向に進んでいると思います。

\section{5. 重要な判決の統一}

では，ここで求められていることは何か。第一 に, 日本版バイ・ドール法の完全導入です。そし て創造的技術, 研究開発に与えられる権利を大学 が一括管理することです。この方向は原則として 大綱でも盛り込まれています。このことは産学連 携にとって非常に大事なことです。

次は活用と保護ですが, 権利をつくり上げると ころと, 権利を活用するところである裁判所の改 革が非常に大事だと思います。プロパテント政策 が進み, 今, 裁判の期間が極端に短くなっていま す。判決の損害賠償額もずいぶん高くなってきて います。さらに日本の裁判制度に求めたいのは, 特許を侵害すれば，それがすぐに明白となる仕組 みを強化すべきであるということです。現在日本 では裁判は公開ですから, 裁判の過程で営業秘密 を明らかにした場合, それを守る制度が限られて います。したがって裁判では, できるだけ営業秘 密を出さないようにしているので, 侵害物の特定 が簡単にできず，判決に時間がかかるのです。侵 害物あるいは侵害方法の特定のために, 営業秘密 でも必要なものは出させ, 出された企業秘密は必 要な人以外には開示せず, 当事者等でそれを見た 人に機密保持責任を持たせ, 違反したら罰則を科 すという仕組みは必要だと思います。侵害したら わかってしまうという仕組みが大事です。また機 密保持の仕組みは, 営業秘密そのものが訴訟の対 象になったときはなおさらです。そうしないとだ れも営業秘密の裁判をやらなくなってしまいます。

米国では, 営業秘密が提出された場合, プロテ クトをかけて普通の人は見られないようにしてい ます。当事者であっても限られた人しか秘密情報 は見られません。そして, 見た人は厳格な義務を 持ちますから，模倣して使うことはできません。
違反すれば非常に厳しい罚則が科せられる。こう いう仕組みで裁判が適用されていますが, 日本の 場合は仕組み自体がありません。ただし, 日本で もいろいろな場面で検討に入ったところですので 期待しているところです。

次は, 損害賠償額をもっと高くする必要がある ということです。日本の場合は実損以上はとれず， 実損を立証することも大変です。実損しか損害賠 償はとれないとなると, これでは軽すぎます。侵 害行為は実損以上の損害賠償が適用されるように しないと権利を尊重する気分は出にくいのではな いでしょうか。このような，権利者から見て研究 開発投資へのリターンが保証されるような裁判の 仕組みがあれば,やみくもに裁判に持ち込むとい うことではなく, その前の解決, 示談もできるは ずだと思います。

私はこれまで40年知財関連の仕事をして，すべ て話し合いで解決するように努力してきました。 訴訟国家である米国と大きく違う点です。現実の 事業を見たとき, 情報産業の分野の商品は多岐に わたる技術で構成され, それぞれの構成技術に複 数の特許が存在するのが普通です。結果として, ひとつの商品は数百もの特許で保護された技術で 構成されているわけです。つまり我々の産業界で は, 1 件や 2 件の特許で争ってもすべてを解決でき ないのです。話し合いで解決しなければならない, そういう業界でもあると言えます。しかし話し合 いがつかない場合, 裁判になればどういうことに なるのかは前提として考えますので, 裁判になっ たらどうなるかは依然として重要であることに変 わりはありません。侵害に対し厳しい判例が確立 していることが事前の話し合いでの解決を可能に するのです。

さらに, 前述しましたように判決の統一は重要 です。米国ではCAFCで判断を1つにしましたが,こ れは多大な効果を持ちました。具体的に言います と, 知的財産の侵害訴訟については大阪地裁と東 京地裁を専属管轄にしてほしい。控訴審は東京高 等裁判所を専属管轄にしていただきたい。専属管 轄にすると同時に, CAFCのような判断の統一がで きるような仕組みを考えていただきたいというの が産業界からのお願いです。この理由は, 技術的 にも高度な専門性を必要とする裁判に対する重点 的な人的強化もさることながら, 企業が研究開発 するとき, 事前に第三者の特許を検討します。そ して, 今実行しようとしていることの侵害の可否 を研究開発する前に判断しなければなりません。 
統一的な判決が出ていないと企業は判断しにくく なる。侵害を避けようとすると，権利的に見て必 要以上に安全なところしか研究開発できなくなり ます。これではロスが多くなります。こういうロ スがあれば産業競争力を高められません。米国は 日本の国土の何十倍もあります。にもかかわらず， 控訴裁判所の管轄を全米で1か所にしました。前に 述べたCAFCです。そして判決の統一を図りました。

知的財産の侵害訴訟でもうひとつ改善すべき点 として, 侵害訴訟が提起された場合は，その裁判 所で権利の有効性と侵害の有無についての両方の 判断を両当事者の攻撃，防御の下一回的に解決す る仕組みが望ましいと思います。裁判所の技術専 門性の補強が前提となりますが, 真実がはっきり するし, トータルの訴訟期間も短縮できると思い ます。

私は昭和35年に知的財産の仕事を開始しました。 特許法は昭和 35 年に改正され，しばらく改正はあ りませんでした。ところが近年, 毎年特許法の改 正があります。企業ができた法律を最大限活用す ればよいという時代ではありません。どういう改 正をすべきか企業側の意見を相当出しませんと, 企業の欲する方向の改正ができないのではないか と思っています。幸いにも現役を退任した今，企 業の立場でいろいろな意味での改正に対して, 産 業界としての望ましい形というのを申し上げてい るつもりです。

\section{6. 立場に応じた知財戦略を}

では，今度は企業の戦略というほうに話を替え てみたいと思います。業界または企業によって， 知財戦略というのはまちまちです。ですから，日 本の経営者のために特許取得管理の指針をつくろ うということが知的財産基本法にも入っています が，個人的にはそのような指針の表現は十分気を つけたほうがよいと思います。理由は，企業それ ぞれに知的財産戦略が異なるからです。要は, 企 業の経営者がまず知的財産が大事であると真に思 い込むことが大事なのです。業界の違い, 研究開 発をしていない会社，あるいは基本的には二番手 でいく会社，あるいは逆に研究開発に相当投資し て，いつも市場を創成するような新しい商品を創 り出す会社, 新しいビジネスモデルでいく会社, あるいは大会社, 中小企業, ベンチャー, 研究機 関, 材料メーカー, 部品メーカー, セットメーカー, デパート的会社，専門店的な会社，それぞれ知財
のやり方が違います。その会社が置かれている立 場に応じた戦略を立てないと効果がないのです。 ということで，一般論をお話しするのは非常に難 しいのですが, 私どもの置かれている産業界, 私 どもの規模を前提にしてお話をしたいと思います。 私どもの会社は, 創立から今まで専門店といっ た企業でセットメーカーなのです。一方，日本の 大手の企業, 特に電機メーカーはデパート的企業 だと思います。それぞれが同じような商品を製造 しています。私どもも，ある種同じような製品を 製造しているわけですが，それはデパート的企業 のそれらの製品の一部です。得意な製品のみです。 そういう会社が知的財産管理を行えば, 自社の事 業を大事にすることになります。そこで大会社が トータルの知的財産に投資するお金と専門店が投 資するお金は，ある特定の商品の技術に限って見 ますと，専門店のほうがはるかに投資額は大きい と言えます。したがってその技術に関しては,デ パート会社より優位な研究開発が通常できます。 よってその商品に関しては絶対的な優位性が保た れます。デパート会社ですと, 事業を有利にする 権利の活用は事実上難しいと思います。知的財産 の活用という点では,まさにデパート会社はデパー トなりの活用しかできないのです。ということは, 特に自分の会社の全製品を有利にする知的財産の 活用はできづらく，同業右へならえの活用しかで きない道理となると考えます。ベンチャーの場合, ハード型ベンチャーで事業を起こすのは, 自前で やるのは非常に大変だと思います。大会社が新規 事業を起こす場合ですら第三者の権利のクリアが 大変です。今, ベンチャー育成が言われています が, ソフト型ベンチャーならいざ知らず, ハード 型ベンチャーが昔風に, ベンチャーがあれだけ大 きな会社になったというようなことは本当に可能 なのでしょうか。当時と今とでは状況がまったく 違います。ですから今は, ベンチャーが成功する スタイルを真剣に考えるべきだと思います。これ については開発型ベンチャーになるか，まずはど こか有利な会社と組んでジョイントベンチャーで やるかといった選択にしないと, 競争に勝つのは 相当難しいと言えましょう。大企業もそうですが, 情報産業の分野の会社を例にすると, 自前では全 部開発できません。内製率なんて $20 \%$ あればよい ほうです。8割は全部外部から部品購入です。しか も購入部品の中身はわからずブラックボックスと して購入しています。そういう状態で全部の知的 財産を自分で責任を持って処理するというのは不 
可能な時代です。

ライバル会社で絶対的に強いあるいは絶対的に 弱いという会社はまれで, 相対的に強いか弱いか です。そこで個々の勝負ではなくて, ライバル会 社の企業対企業の技術力関係を見て, その背景と して特許が存在することを認識することは必要で すが，基本的には自社の有利な技術を相手に渡さ ず，相手の有利な技術をいかに自社に取り込むか が競争力を高める基本となります。戦略的な交涉 力が重要なのです。内部的には, 知的財産と事業 の人たちが連携をとることです。この場合, 事業 が主役で, 知的財産はわき役で，そこでは事業が 成功するために知的財産をどう取得してどう活用 するかに専念すべきだろうと私は思っています。

知的財産部の人たちは何をすべきか。まず, 自 分の会社の事業を知ること，技術を知ることです。 自社で開発した技術は事業に有利になるような形 で権利取得しなければいけない。したがって, 何 が事業にとって大事かという技術評価ができなけ ればいけない。あるいは逆に言うと, 何を課題に して研究開発しているかを理解しなければいけま せん。そして，それを理解したうえでもつと大事 なのは, 事業の実施に有効な特許をとることと, 先行技術との区別をはっきりさせることです。

特許権は, 先行技術とぎりぎりの線で権利をと るのが, 発明を技術思想として権利がとれるので いちばん効果的です。あまり広くとって先行技術 をカバーしてしまったら，無効理由を持つことに なってしまいますし, 発明の実施形に限ってとっ たのでは権利が狭すぎて, 大事な技術思想を公開 してしまったことになり，企業にとっての損失は 計り知れません。したがって，良い権利をとれる かは, 先行技術をいかに理解しているかが最大の ポイントになります。非特許文献, 特許文献の把 握も重要です。先行技術との区別をつけないと, 本当に良い権利はとれないからです。

\section{7. 大学に知的財産戦略を}

私は基本的な発明を大学に期待すると申しまし たが, 現在, 大学にそんな特許をとる技量がある だろうかと懸念します。企業でも大変な仕事です から, 大学で大事な発明が出て, それを実際に事 業にするときに, 事業に有利になるような権利の 取得ができるだろうかということです。ですから， 産学連携は早い時期に企業と組んで, 企業に知的 財産上の戦略をとらせるべきだと思います。そう
することが, 企業にその技術の事業化意欲を起こ させる大事なことだと思います。大学が技術を温 めている期間が長いほど, 戦略的知的財産取得の チャンスが失われます。今は特許出願は 1 年半で公 開されます。公開されると, 内外の研究開発者は それをべースに事業化に必要な改良特許をとるこ とが可能です。さらに言えば，米国の特許制度を 利用すれば, その教官の, 例えば日本の学会での 発表を聞いて, 自らの特許出願にそれを盛り込む ことができます。

「特許なんかとって独占するのはよくない」とい う意見も大学の先生から聞くことがあります。し かし，それは国益に反しましょう。まず，特許を とってください。権利を活用するかどうかは後の 問題です。まずとらないことには, 国費を負担し た日本の企業だけ被害を受けるのです。そういっ た技術を利用して外国の企業が特許をとったら， 我々が被害を受けるのです。加えて, 国内だけで 特許をとっても日本のマーケットを守るだけで国 際競争力は高まりません。やはり外国の特許をと らなければなりません。外国の特許をとらないと 外国の企業に対するプレッシャーになりません。 そうなると, 大学には研究だけではなく, 知的財 産戦略も求められます。大綱の中でも, 大学に知 財本部をつくることがうたわれています。ただ, 企業の中の知財本部も, それだけの機能を果たす には時間がかかります。大学の知財本部が本当に 機能を果たすためには相当時間がかかると思いま すので, それまでの間は企業がバックアップしな いと, せっかくの大学での優れた発明が大した権 利にならないで終わってしまうことになりかねま せん。

もうひとつは, 日本の先願主義から来る問題が 挙げられます。米国がとる先発明主義とは異なり, 先願主義では基本発明を基本特許としてとるには 不利です。私は基本発明が基本特許としてとりや すい仕組みを考えるべきだと主張していますが, 検討はしていただいているようです。こういうこ とも含めて総合的にやらないと, 競争力は高まら ないというのが, 私の考えであり, 産業界の意向 です。

（文責＼cjkstart本誌編集事務局）

このあと, 会場からの質問に対する講演者の回 答があったが, 誌面の都合上, 割愛させていただ いた（事務局記）。 